\title{
AFFIRMATIVE PURSUIT OF POLITICAL EQUALITY FOR ASIAN PACIFIC AMERICANS: RECLAIMING THE VOTING RIGHTS ACT
}

\author{
SU SUN BAI $\dagger$
}

The participation of Asian Pacific Americans ${ }^{1}$ in the American political process has recently attracted significant media attention as the mainstream political leadership has come to recognize a growing enclave ${ }^{2}$ of potential votes ${ }^{3}$ and other forms of valuable support. ${ }^{4}$ Popular perceptions of Asian Pacific Americans as an

† A.B. 1987, Harvard University; J.D. Candidate 1991, University of Pennsylvania. I would like to thank Professor Lani Guinier of the University of Pennsylvania Law School and Professor Don T. Nakanishi of U.C.L.A. Graduate School of Education for their invaluable advice and encouragement. This Comment is dedicated to my parents and all immigrants "from a different shore."

1 The term "Asian Pacific American" encompasses those nationality groups that were listed separately in the 1980 census questionnaire. They are the Chinese, Filipino, Japanese, Korean, Asian Indian, Vietnamese, Hawaiian, Samoan, and Guamanian nationality groups. There are additional identifiable groups which were not listed separately on the census form but which fall under the category of "other."

${ }^{2}$ In the last 25 years, since the relaxation of anti-Asian restrictive immigration laws, the Asian Pacific American population has increased steadily and dramatically. Studies predict that by the year 2000, the Asian Pacific American population will account for $4 \%$ of the general population, and in states with large Asian Pacific American communities such as California, Asian Pacific Americans will make up over $10 \%$ of the state's population. See Stokes, Learning the Game, 20 NAT'L J. 2649 (1988) (stating that the Asian population in the United States will grow to nearly $4 \%$ by the year 2000); Wong, Asian Americans Shake off Stereotypes, Increase Clout as Political Activism Grows, L.A. Times, Feb. 23, 1988, at 7, col. 1 (noting that the Asian population in California will rise to more than $10 \%$ of its total population by the year 2000).

${ }^{3}$ In the 1988 presidential race, and other recent elections, both the Republican and Democratic candidates attempted to portray themselves as the promoters of Asian Pacific American interests. See, e.g., Courting the Eager Asian-Americans, 19 NAT'L J. 2265 (1987) (noting the rising interest of Republican organizers in "tapping support from the nation's fastest-growing racial group"); Dao \& Chan, Wooing Asian Americans: Who does it Best?, Asian Times, Apr. 1988, at 1, 7; Johnson \& Edsall, Asian Americans Torm Between Two Parties, Wash. Post, June 2, 1984, at A1, col. 1 (noting the growing political power of Asian Americans which is gaining recognition by both the Democratic and Republican parties).

4 Asian Pacific Americans have received much attention for their generous campaign donations. See, e.g., Asian Checkbooks Active in Campaign, Asian Times, 
economically successful minority group 5 have helped to foster the expectation of a developing political power within the Asian Pacific American community; an expectation which, to a certain degree, appears to have been valiclated. ${ }^{6}$

The actual level of Asian Pacific Americans' political participation, however, has failed to rise either in proportion to their increasing numbers or in accordance with popular expectations. ${ }^{7}$

Nov. 1989, at 7, col. 6 (noting that New York City's 1989 mayoral campaign "saw an unprecedented number of Asian American political fundraisers" and an estimated total of $\$ 60,000-80,000$ in Asian American contributions to the new mayor, David Dinkins); Chan, Cashing in on Democracy-Rep. Solarz Makes Fighting for Freedom in Asia Pay, Asian Times, Apr. 1989, at 4, col. 1 (stating that Rep. Stephen J. Solarz (D-Brooklyn), chairman of the House Foreign Affairs Subcommittee on Asian and Facific Affairs, has the second largest campaign chest of $\$ 1.2$ million in the House, three-fourths of it from Asian Pacific Americans from all over the country); Dao, Asian Political Investments: Will they Bring Returns?, Asian Times, Apr. 1988, at 7, col. 6.

5 For a discussion of the "rnodel minority" thesis, see infra notes 57-65 and accompanying text.

6 Not only did Japanese Americans succeed in garnering reparations for surviving internment victims, see Redress Becomes Law, OUTLOOK, Spring 1989, at 1 , but the Asian Pacific American collective has been largely successful in fighting quotas against Asian Pacific American admissions to top colleges. See DeWitt, U.S. Expands Inquiry of College Bias, N.Y. Times, Oct. 3, 1990, at B3, col. 1 (reporting that the U.S. Department of Education is investigating admission policies at Harvard, the University of California at Berkeley, and the University of California at Los Angeles for alleged bias against Asian Pacific Americans); Johnson, Wider Door at Top Colleges Sought by Asian Americans, N.Y. Times, Sept. 9, 1989, at A1, col. 2 (noting that "Asian-American scholars, education officials and political leaders say they are pursuing new avenues" to redress disproportionately low admission rates for Asian Pacific Americans).

7 Professor Don T. Nakanishi of UCLA's Asian Pacific American Studies Center, for example, cautions in the beginning of his article, Asian American Politics: An Agenda for Resea1ch, that although Asian American politics is becoming increasingly significant and more Asian Pacific Americans are becoming politically involved,

[i]t would be incorrect ... to conclude from these recent developments that Asian Americans have become powerful and unified.... In most regions-aside from Hawaii-and at higher levels of state and federal decision-making, they remain largely unrepresented. At best, their impact has been regional and sporadic, and their reputed success as a model minority disguises their lack of representation in the most significant national arenas and institutions.

Nakanishi, Asian American Politios: An Agenda for Research, AMERAsIA J., vol. 12, no. 2, 1985-86, at 1, 1-2 (footnote omitted); see also Cain, Asian-American Electoral Power: Imminent or Illusory?, 5 ELECTION POLITICS 27, 28 (1988) (noting that "Asians score well on the demographic indicators that predict high political participation, but their actual participation levels are comparatively low"). 
Attempts to understand the phenomenon of Asian Pacific American political silence have emphasized cultural differences, ${ }^{8}$ the difficulty of combining Asian Pacific American subgroups into a cohesive "minority" group because of their diverse nationalities and generations, ${ }^{9}$ and their lack of interest in politics.

This popular preconception of Asian Pacific Americans as a politically silent "model minority" is just one of the many barriers

8 Cultural differences often mentioned include Confucian values of reverence for authority and obedience, the supposed non-adversarial nature of Asian cultures, and an unfamiliarity with democratic systems. See Gross, Diversily Hinders Asians' Power in U.S., N.Y. Times, June 25, 1989, at A22, col. 1 (noting that the development of an Asian Pacific American political consciousness has been hindered by, among other things, "cultural and religious values that discourage the strivings of partisan politics"). But see Tong, The Ghetto of the Mind: Notes on the Historical Psychology of Chinese America, AMERASIA J., Nov. 1971, at 1, 7-8, 14-15 (arguing that the supposed subservient personality of Chinese Americans only developed in response to anti-Asian directives and became internalized over time, and further, that the first Chinese immigrants were a dynamic group who had been active in the peasant rebellions in China protesting corruption and injustice). Another author argues that "[i]dentity is therefore not the problem of Asian Americans, and it is not one that is solvable in personal terms," but rather the

problem stems from the historical choice Asian Americans made to live in this society, from their necessary involvement with it, and from the racism they encounter from its institutions and its inhabitants. Identity dilemmas are only the flashpoints which, upon investigation, disclose to us the real nature of the difficulty of living in a racist society, some of whose effects on Asian Americans have been to disarm them of an awareness and an ability to resist the total impact of racism's degrading consequences. Identities imposed and chosen in racist circumstances must be transcended to be seen for what they are.

Surh, Asian American Identity and Politics, AMERASLA J., Fall 1974, at 158. Surh thus calls for a "[r]adical, political resistance [as] the only road that will make it possible both to address the full scope of the problem and to choose the course of liberation from a situation originally created by others, but also elected by Asian Americans themselves." Id.

9 See Gross, supra note 8, at A22, col. 1 (arguing that the "primary

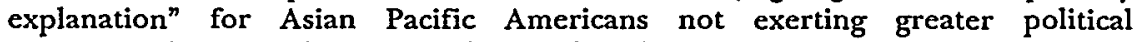
power in the United States today is that "Asian-Americans are pulled apart by their diverse nationalities, languages, religions, and historical animosities").

This type of analysis is common among the current media's attempts to understand the political behavior of Asian Pacific Americans. See, e.g., Rothenberg \& McGurn, The Invisible Success Story: Asian Americans and Politics, 41 NAT'L REV. 43 (1989) (noting that the heterogeneous nature of the Asian American community hinders its political impact); Rogers, Diversity of U.S. Asian Vote Presents Parties with Courtship Challenges and Opportunities, Wall Street J., June 1 , 1988, at 56, col. 3 (noting that "[ $t]$ he multitude of languages and very diversity of the Asian-American community makes it harder to organize"). 
facing Asian Pacific Americans who desire to enter the political process. Asian Pacific A.mericans also face the many barriers to effective representation that have traditionally confronted other racial and ethnic minority groups. Obscured by the popular hype which labels them as the "successful" minority, however, Asian Pacific Americans are viewed either as not warranting special protection from official discriminatory practices or as already participating greatly in the political process. ${ }^{10}$

This Comment will focus on the discriminatory barriers to voting and voter registration which confront non-English speaking Asian Pacific Americans, and on the effect of vote dilution that has disfranchised and excluded many Asian Pacific Americans from the political process. The fundamental reasons for the lack of political participation by Asian Pacific Americans are the existing barriers they face as both racial and language minorities. As racial minorities, Asian Pacific Americans have been systematically excluded from full participation in American society in general and have been victims of the racist barriers and facially neutral dilutive mechanisms ${ }^{11}$ which were originally erected to disfranchise African Americans, but which worked to disfranchise Asian Pacific Americans as well. Similarly, as language minorities, they confronted the disfranchising mechanisms traditionally directed against Hispanic Americans. ${ }^{12}$

Nevertheless, the distinct situation of Asian Pacific Americans works to hinder their ability to utilize the judicial and legislative remedies afforded by the Voting Rights Act of 1965, as amended in $1982,{ }^{13}$ as well as their ability to take advantage of the relevant vote dilution case law concerning other minority groups to promote their inclusion in the political process. ${ }^{14}$ Analyzing the Voting Rights Act and its resulting case law from the perspective of Asian Pacific Americans thus provides a window to examine, and redefine,

10 See, e.g., Ueda, False Modesty: The Curse of Asian American Success, NEw REPUBLIC, July 3, 1989, at 16 (alleging the "success" of the Asian American community as evidenced by high incomes, good jobs, and strong presence at elite universities); Graham, Can Divisiveness Really Unify Asian-Americans?, N.Y. Times, July 20, 1989, at A22, col. 4 (criticizing a news story which had noted political disunity among Asian Americans).

11 See infra notes 109-34 and accompanying text.

${ }^{12}$ See infra notes $135-48$ and accompanying text.

${ }^{13}$ Pub. L. No. 97-205, 96 Stat. 134 (codified as amended at 42 U.S.C. $\S 1973$ (1988)).

14 This is not to suggest that the available remedies have cured the situation of other minority groups. 
the inadequacies of currently available remedies for all minority groups.

Part I of this Comment outlines the problem of the exclusion of Asian Pacific Americans from American politics and society while discrediting and revealing the fallacies of the popularly accepted explanations for this exclusion. Part II traces the history of legal barriers that have hindered Asian Pacific American political consciousness and activity. Part III presents existing barriers and argues that the available remedies fail to protect Asian Pacific Americans effectively. Part IV suggests possible judicial strategies to target and remedy the problem fully and suggests that the Voting Rights Act should be amended to include actual, not just promised, protection for Asian Pacific Americans. Finally, the Comment concludes that both Congress and the judiciary must affirmatively assert their leadership in devising and implementing innovative and effective solutions to the problem of minority political exclusion, thereby politically empowering Asian Pacific Americans.

\section{The Problem of Low Asian Pacific AMERICAN POLITICAL PARTICIPATION}

\section{A. Complete Integration Hypothesis Refuted}

A common assertion that the lack of political participation by a cohesive Asian Pacific American group is due to their complete integration into the American political process and assimilation into American society is disproved by empirical evidence. ${ }^{15}$ Disproportionately low levels of Asian Pacific American participation in both electoral and nonelectoral politics, as compared to that of the general population, suggests that Asian Pacific Americans actually are not assimilated into the American political mainstream. ${ }^{16}$ This Comment focuses on three areas with significant Asian Pacific American populations-Los Angeles, San Francisco, and New York

15 For references to such arguments of integration, see Roskin \& Jo, AsianAmerican Political Participation, in POLITICAL PARTICIPATION OF ASIAN AMERICANS-Problems and STrategies 111 (Y. Jo ed. 1980) [hereinafter Political PARTICIPATION] (noting various models and theories which analyze the lack of cohesive Asian Pacific American political participation); see also Rothenberg \& McGurn, supra note 9, at 44 ("Asian-Americans are very different from other American minorities. Their voting preferences resemble the white (Anglo) electorate's, even if their rate of participation is far lower.").

${ }^{16}$ See infra notes $19-48$ and accompanying text. 
City ${ }^{17}$-to investigate the present problem of low political participation by Asian Pacific Americans. ${ }^{18}$

\section{Lack of Electoral Political Participation}

\section{a. Low Voter Registration Figures}

The UCLA Asian Pacific American Voter Registration Study (UCLA Study) found that Asian Pacific Americans accounted for $6.0 \%$ of the total Los Angeles County population and comprised between $2.9 \%$ $4.3 \%$ of the total electorate of that county in $1980 .{ }^{19}$ In all of the communities studied, Asian Pacific Americans demonstrated a lower voter registration rate than other residents, and the "proportion of Asian Pacific American voters in relation to local electorates [wa]s usually far less than the proportion of Asian Pacific Americans in the total population of these communities."20 The Asian Pacific American voter registration rate was well below the overall county average of $60 \%$ for all individuals 18 or older. Specifically, the highest Asian Pacific American registration rate of $43.0 \%$ was that of Japanese Americans, followed by a rate of $35.5 \%$ for Chinese Americans, $27.0 \%$ for Filipino Americans, $13.0 \%$ for Korean

17 Hawaii will not be examined because of its idiosyncratic nature. Not only do Asian Pacific Americans comprise a majority of the population in Hawaii, but Hawaii's unique history (joining the union in 1959) distinguishes it from the mainland society's type of minority-majority relations. See $\mathrm{Ng}$, Asian-American Politics in Hawaii, in POLITICAL PARTICIPATION, supra note 15, at 90. $\mathrm{Ng}$ laments the lack of Asian American studies that integrate an analysis of Hawaii and alludes to some factors behind this common oversight. He notes "the complexity and different ethos of Hawaiian politics," Hawaii's not "fit[ting] into a scheme of Asian-American politics for the mainland," and its being a "cultural puzzle" for mainland Asian Americans to understand. He further notes that "almost all the interpreters of contemporary politics in Hawaii seem to concur that votes are cast on the basis of economic and social considerations rather than race or ethnicity." Id. at 96.

18 These three areas were chosen for a number of reasons: high concentrations of Asian Pacific Americans in the area relative to other areas, a history of systematic exclusion and discrimination against Asian Pacific Americans in these areas, and the existence of some research and documentation of political participation. See G. Din, An Analysis of Asian/Pacific American Registration and Voting Patterns in San Francisco 1-15 (Nov. 29, 1984) (M.A. Thesis prepared at Claremont Graduate School); D. Nakanishi, The UCLA Asian Pacific American Voter Registration Study, at i-iii (1986) [hereinafter UCLA Study]; see also Stokes, Leaming the Game, 20 NAT'L J. 2649, 2650 (1988) (noting that three out of five Asian Pacific Americans are located in California, Hawaii, and New York).

${ }^{19}$ See UCLA Study, supra note 18 , at $i$.

${ }^{20} \mathrm{Id}$. 
Americans, $16.7 \%$ for Asian Indians, $28.5 \%$ for Samoans, and the extremely low $4.1 \%$ for Vietnamese Americans. ${ }^{21}$

A similar study done in San Francisco compared Chinese and Japanese American voter registration rates to those of the general population in three electoral districts with high concentrations of Asian Pacific American populations and found Asian Pacific American rates to be extremely low. ${ }^{22}$ For instance, only $30.9 \%$ of the Chinese Americans in the San Francisco area were registered to vote in contrast to the $69.1 \%$ voter registration rate for non-Chinese (and non-Asian Pacific American) citizens. ${ }^{23}$ The estimated number of Chinese American voters in the San Francisco area was about $5.5 \%$ of the total number of voters when the Chinese American population in 1980 was $12.1 \%$ of the city's total population. ${ }^{24}$ Japanese Americans in these districts also demonstrated overall low registration figures with only about $39 \%$ registered to vote. ${ }^{25}$ Even if the low Chinese American voter registration rate can be explained partly by the high percentage of those who are foreign born, the possibility of non-citizenship status still fails to explain adequately the low registration rate of Japanese Americans who are predominantly American born. ${ }^{26}$

In sum, Asian Pacific Americans are "grossly underrepresented in terms of their voting power in relation to their numbers in the population." ${ }^{27}$ As a consequence, the study of San Francisco accurately predicted that Asian Pacific Americans will have "a lack of say in decisions that affect them the most, such as bilingual ballots, Chinatown development . . . and less of a likelihood to elect Asian/Pacific candidates than their numbers would indicate." 28

Although no formal study has been done for the New York Gity area, the problem of low voter registration among the Asian Pacific American community in New York has been documented. For

${ }^{21}$ See id. at i-ii.

22 See G. Din, supra note 18, at 63, 79, 85.

${ }^{23}$ See id. at 79,86 . Chinatown's registration rate of $23.1 \%$ was particularly low. See id. at 82 .

${ }^{24}$ See id. at 86.

${ }^{25}$ See id. at 85.

${ }^{26}$ See id. at 85, 126 (stating that $39.1 \%$ of Japanese Americans registered to vote in the Richmond district and $31.5 \%$ registered in the Sunset district). As Din observes, "[c]learly the registration rate [of Japanese Americans] is lower than for the population as a whole and very close to the Chinese rate." Id. at 85 .

27 Íd. at 86.

${ }^{28} I d$. 
instance, a 1984 informal survey by a community organizer found that

the percentage of voting-age adults who registered to vote in [New York's] Chinatown that year was only 25 per cent compared with 47.2 per cent for Manhaltan as a whole: in addition, in districts where Ghinese represented more than 90 per cent of the total population, only 30 per cent of the voters in the 1984 Democratic primary were Chinese. ${ }^{29}$

This survey indicates that the lower registration rate of Chinese Americans in New York City cannot be attributed simply to the possibility of their noncitizen status. ${ }^{30}$

Consequently, as the New York State Advisory Committee to the United States Commission on Civil Rights reports, because of a perceived lack of political power, Asian Pacific Americans are not consulted in formulating policies that affect them, are deprived of benefits, are subject to subtle discrimination, and have "no place... in the regular Democratic or Republican party machinery."31

\section{b. The Low Number of Elected Officials Relative to the Number of Asian Pacific American Voters}

The three urban areas with high concentrations of Asian Pacific American populations also exhibited disproportionately low numbers of elected officials of Asian Pacific American descent relative to their population numbers-a further sign of political exclusion. ${ }^{32}$

29 Kwong \& Lum, Chinatown: Rousing a Political Giant, A Chance to Build Coalitions, Village Voice, Apr. 12, 1988, at 10, 12, cols. 4-5.

30 As one commentator observes, "[w]hile citizenship is a requirement for voting in other than school-board elections, it does not necessarily lead people to vote-particularly people who speak neither English nor Spanish." Roberts, New York's Immigrants Aren't Rushing to Politics, N.Y. Times, July 22, 1989, at 28 , col. 5 .

${ }^{31}$ NEW YORK STATE ADVISORY COMMITTEE TO THE UNITED STATES COMMISSION ON CIVIL RIGHTS, ASIAN AMERICANS: AN AGENDA FOR ACTION, A CONFERENCE SUMMARY 39 (1980) [hereinafter ASIAN AMERICANS: AN AGENDA FOR ACTION]. The Committee elaborates that "by and large Asian Americans in New York have been indifferent to the political system because they have never been a part of it. They are scattered all over the city, and, except for Chinatown, the politicians have never wooed them for their votes." Id. at 40 .

32 On the other hand, the election of Asian Pacific American public officials would be a sign of their inclusion in the political process. For instance, in the case of black electoral politics, majority electoral success for blacks has been shown to produce greater identification among black voters with black candidates, greater participation in politics, and a greater 
California, for example, has the largest concentration of Asian Pacific Americans in the nation, ${ }^{33}$ and many estimate that Los Angeles County's Asian Pacific American population will have doubled in size by 1990 with current rates of overseas immigration and domestic, secondary migration. ${ }^{34}$

Nevertheless, as of 1986, no Asian Pacific American had ever been elected to a county-level position in Los Angeles, there had been only one Asian Pacific American member of the state legislature from Los Angeles, ${ }^{35}$ and there had been only two Asian Pacific American congressmen from California (moreover, both Robert Matsui and Norman Mineta were elected from Northern California). ${ }^{36}$ The UCLA Study, however, does recognize some improvement, stressing that the existence of elected Asian Pacific American public officials "nonetheless represents a significant degree of progress, especially when it is measured against the long history of total non-representation of Asian Pacific Americans in local politics." 37 Similar underrepresentation by elected officials is evident in San Francisco, New York City, and across the nation in general. ${ }^{38}$

sense of inclusion in the political process as equal citizens. See, e.g., Guinier, Keeping the Faith: Black Voters in the Post-Reagan Era, 24 HARV. C.R.-C.L. L. REv. 393, 417 (1989) (arguing that "[p]eople participate 'where, when and how' they think it matters"); Karlan, Maps and Misreadings: The Role of Geographic Compactness in Racial Vote Dilution Litigation, 24 HARV. C.R.-C.L. L. REV. 173, 180, 215 (1989) (arguing that the values of civic inclusion of racial minorities are a "sense of connectedness to the community and of equal political dignity" and "greater readiness to acquiesce in governmental decisions and hence broader consent and legitimacy"). Karlan emphasizes that racial diversity in elected offices is a "powerful symbolic statement" and "may help to dispel the sense that these positions are reserved for whites and may encourage greater minority participation by creating a sense of political efficacy and membership in the governing community." Id. at 215.

33 California's Asian Pacific American population comprises nearly $40 \%$ of the total Asian Pacific American population in the U.S.. See Gross, supra note 8 , at A22, col. 1 .

${ }^{34}$ See UCLA Study, supra note 18, at 1-2 (remarking that as a consequence, "the issue of fair and equitable political representation and access will become even more paramount for Asian Pacific Americans"); Barringer, Asian Population in U.S. Grew by $70 \%$ in the $80^{\prime}$ 's, N.Y. Times, Mar. 2, 1990, at A14, col. 1; Mathews, Califormia's Asians Outnumber Blacks: Demographic Shift Marks Emergence of Swing Political Group, Wash. Post, Apr. 24, 1988, at A3, col. 3.

35 The one exception is California state Assemblyman Paul Bannai who served in the mid-1970s. See UCLA Study, supra note 18, at 2.

36 See id. Matsui, Mineta, and Matsunaga of Hawaii were also the only Asian Pacific American congressmen in the nation.

${ }^{37}$ Id. (emphasis added).

38 As of 1984 , there were no city or county level officials of Asian Pacific 


\section{c. Weak Party Affiliation}

Another possible sign of the political exclusion of an identifiable group is the lack of strong political party identification within the group. ${ }^{39}$ Although the Democratic party has been the overwhelming choice of minority groups, this does not necessarily seem the case with Asian Pacific Americans. In Los Angeles County, for instance, most political subdivisions show a plurality or majority of Democrats among Asian Facific Americans. This figure, however, is usually less than that of the electorate as a whole. ${ }^{40}$ The San Francisco study also points out weak party affiliations of Chinese Americans in San Francisco, and in particular, the significant percentage that declined to state any party affiliation. ${ }^{41}$

In addition, exit polls conducted by the Asian American Legal Defense and Education Fund (AALDEF) after the recent presidential and mayoral elections at New York City voting sites revealed a "willingness among Asians to cross party boundaries." 42 In the mayoral race, for instance, 53\% of the Asian Pacific Americans surveyed in the Flushing area voted for Republican Rudolph Giuliani and $40 \%$ voted for Democrat David Dinkins even though only $30 \%$ claimed to be registered Republicans. ${ }^{43}$

This lack of party identification, however, does not mean that Asian Pacific Americans do not form a politically cohesive group. ${ }^{44}$

descent in San Francisco or New York City. See ASIAN AMERICAN STUdies Center, National Asian Pacific American Roster: 1984, at 1-3, 13 (1984).

39 Because political parties have excluded Asian Pacific Americans from party politics in the past and have ignored their interests except in very recent elections, Asian Pacific Americans have not identified with either party. Rather, Asian Pacific Americans act together on issues that reflect their concerns and interests, and vote for candidates whom they feel will represent their interests. These candidates can be either Republicans or Democrats since Asian Pacific American interests are not tied to one party. See G. Din, supra note 18, at 20-26; see also Cain, supra note 7, at 29 (stating that "the Asian vote, to some degree, is up for grabs by both Democrats and Republicans").

${ }^{40}$ See UCLA Study, supra note at 18, at 22-23.

41 See G. Din, supra note 18, at $92-93$ (stating that in 1983, 28.3\% registered as "decline to state").

42 Getting Out the Vote: AALDEF Exit Poll Shows Need for Education, OUTLOOK, Spring 1989, at 2. [hereinafter Getting Out the Vote].

${ }_{43}$ See AALDEF Surveys Voters. OUTLOOK, Summer 1990, at 3. In addition, $49 \%$ of the Asian Pacific Americans surveyed after the 1988 presidential election voted for Bush and $40 \%$ voted for Dukakis even though only $17 \%$ claimed to be registered Republicans. See Getting Out the Vote, supra note 42, at 2.

${ }^{44}$ For a discussion of evidence of cohesion, see infra notes 71-77 \& 132-35 and accompanying text. 
Rather, it only indicates that Asian Pacific Americans are not fully integrated into the political mainstream and thus are not bound by traditional party ties. ${ }^{45}$

In sum, the low Asian Pacific American voter registration rates, along with weak party affiliations and the low number of elected officials of Asian descent, all attest to the political exclusion of Asian Pacific Americans.

\section{Lack of Broader Political Participation}

The level of Asian Pacific American participation in nonelectoral politics is also below that of the general American population. The same reticence seen in electoral politics is demonstrated in such nonelectoral activities as caucusing, lobbying, campaigning, fundraising, and attempts to influence policy. ${ }^{46}$ Admittedly, there has been a dramatic increase in Asian Pacific American financial contributions to political campaigns. ${ }^{47}$ Nevertheless, as the UCLA Study attests, these donations

ha[ve] not consistently resulted in greater attention being paid to the needs and concerns of Asian Pacific American communities, or in increased access to political decision-making. Indeed, a growing number [of Asian Pacific Americans] believe that their financial resources could be better used in further supporting a number of vital, and yet financially strapped, community-based

45 See G. Din, supra note 18, at 20. Neither party has a solid history of representing or recognizing valid Asian Pacific American interests. "The first major dealings between Asian/Pacific Americans and the major political parties took place in the 1860's and 1870's. In fact, as early as 1852 the Democratic party passed their first anti-Chinese resolution at their statewide convention in Benicia, California." Id. (citing J. CHEN, THE CHINESE IN AMERICA 136 (1980)). The Republican party was also quick to dismiss the equality of Chinese Americans in their 1869 platform, stating that "[w]e are opposed to Chinese suffrage in any form and to any change in the naturalization laws of the United States." Id. (quoting V. LOW, THE UNIMPRESSIBLE RACE 29 (1982)). As Din pointedly states, the parties "wanted [Chinese American] labor but not their political power." Id.

46 See, e.g., Cain, supra note 7, at 28 (table indicating low Asian American participation in campaigning, political rallying, and fundraising activities); Iwata, For Asians, 'Great Wall'Must Break, L.A. Times, Sept. 2, 1988, at 7, col. 1 (home ed.) (noting the correlation between Asian American cultural values and the relatively low number of Asian Americans entering politics and other fields in which strong verbal and social skills are required); Chin \& Parr, Asian Americans: Affluent, Educated-Politically Silent, L.A. Daily J., Oct. 19, 1982, at 4, col. 5 (pointing out that Asian Americans "lack[] the visibility and power to influence government decisions, or to win esteem in the media").

${ }^{47}$ See supra note 4. 
organizations, as well as encouraging the development of potential Asian Pacific American candidates who might seek public office in their local communities. ${ }^{48}$

Thus, Asian Pacific Arnericans are not included in the mainstream American political process. They are greatly underrepresented both as individuals and as a group.

\section{B. Incomplete Socio-Cultural Explanations}

Commentators on the problem of Asian Pacific American political inactivity have focused primarily on personality and cultural traits of Asian Pacific Americans to explain their "disinterest" and lack of activity in American politics. ${ }^{49}$ Scholars in Asian Pacific American studies have also called for greater education and mobilization of the Asian Pacific American population to combat the problem of political inactivity. A common theory asserts that this problem stems mostly from within the Asian Pacific American communities because of the innate socio-psychological characteris$\operatorname{tics}^{50}$ of Asian Pacific Americans which hinder the formation of an effective political power base. ${ }^{51}$ This Section argues, however, that socio-cultural explanations rely on incomplete analysis and false assumptions and do not adequately address the problem of Asian Pacific American political exclusion.

\section{Elements of Validity in Theories}

Socio-cultural explanations do assert some valid points and observations. A degree of divisiveness within the generic Asian Pacific American group stems from generational, national, and historical differences among the various subgroups. This "internal diversity-of ethnic origins, generations, social classes, political perspectives, and organizational aims-has ofttimes prevented [Asian Pacific Americans] from being perceived as a unified actor in articulating their stands on public policy. ${ }^{.52}$

48 UCLA Study, supra note 18 , at 2-3.

49 See G. Din, supra note 18 , at $32-36$ (summarizing the studies on Asian Pacific American personality traits); supra notes 8-10 and accompanying text.

50 For consistency and clarity, this Comment refers to this type of theory as a "socio-cultural" explanation.

51 See Surh, supra note 8, at 158.

52 Nakanishi, supra note 7, at 1; see also Roskin \& Jo, supra note 15, at 112 (listing "cohesiveness or solidarity of the group" as a variable for effective political participation). 
Another often cited factor with some validity is the Asian Pacific American community's unfamiliarity with American political processes due to the fact that a majority of the community consists of recent immigrants with neither the time nor resources to engage in politics. ${ }^{53}$ This unfamiliarity in turn has led to a certain level of disaffection with the political system, which furthers skepticism among Asian Pacific Americans about their political efficacy. In addition, a historical lack of political responsiveness to Asian Pacific American interests ${ }^{54}$ has forced many Asian Pacific Americans into segregated ethnic enclaves such as the Chinatowns, little Tokyos, Manila towns, and Koreatowns of the United States, with very few resources to integrate into mainstream society. ${ }^{55} \mathrm{~A}$ prediction of

53 See G. Din, supra note 18, at 82 (observing that "when the percentage of foreign born residents goes up in an area, the voter registration goes down"); UCLA Study, supra note 18, at ii (attributing the low voter registration rates of Asian Pacific Americans to factors such as "the large number of recent Asian Pacific immigrants and refugees who have not become citizens; the lack of adequate programs for the so-called 'resocialization' of recently naturalized citizens to American political views and processes").

Nevertheless, the UCLA Study also emphasizes that a significant factor for low voter registration is "the historical legacy of political disenfranchisement (in which early Asian immigrants were denied the right of naturalization)." Id. at ii. For a full discussion of this historical legacy, see infra notes 84-107 and accompanying text.

54 For instance, in 1982, New York City built an extension of a prison in Chinatown despite the fact that 12,000 Chinese residents demonstrated in protest. One City Council member commented that "the Chinese lost the battle because they had absolutely no political clout." Kwong \& Lum, supra note 29, at 10, col. 1. Similarly, although Japanese Americans have attempted to assimilate and enter American politics (today most of the few elected national officials of Asian descent are Japanese American), it took over 30 years for the Japanese American Citizenship League to secure reparations for Japanese American interned citizens and most of that sum has not yet been allocated in the federal budget-an indication of the difficulties encountered in attempts to effect legislative and policy outcomes that reflect Asian Pacific American interests. See G. Din, supra note 18, at 23 (citing R. DANIELS, The Japanese, in ETHNIC LEADERSHIP IN AMERICA (1979)).

In addition, many of the progressive federal agencies created under the aegis of the U.S. Commission on Civil Rights have encountered budgeting problems and lack of support from recent administrations. The Commission on Civil Rights recently published another study on the socio-economic status of Asian Pacific Americans which concluded tersely that the by now disproven "model" of success concerning Asian Pacific Americans may still have some validity. See U.S. COMM'N ON CIVIL RIGHTS, THE ECONOMIC STATUS OF AMERICANS OF ASIAN DESGENT: AN EXPLORATORY INVESTIGATION (1988).

55 These ethnic enclaves do not have a sufficient number of Asian Pacific American registered voters or those qualified to register (i.e. those with citizenship status) to form compact single member electoral districts. Thus, a possible electoral benefit of residential segregation (the formation of 
the future of Asian Pacific Americans' political participation thus cannot ignore the possibility that they may become even further alienated from the system. ${ }^{56}$

\section{Problems With Theories}

The basic thrust and erroneous assumption of the socio-cultural hypothesis is that the lack of political participation by Asian Pacific Americans is their own fault, and not that of the system. A 1966 article for the New York. Times, entitled Success Story, Japanese American Style, can be credited with first imposing the egregious honor of the "model minority" on the Asian Pacific American community. ${ }^{57}$ This first positive assessment of Japanese Americans was transferred to a similar discussion about Chinese Americans in a 1966 U.S. News $\mathcal{E}^{\circ}$ World Report article entitled Success Story of One Minority Group in U.S. ${ }^{58}$ Thus the image of Asian Pacific Americans changed from the "yellow peril" of the World War II era to the "model minority" of the 1960 s at a time when the country was

single member districts) remains elusive for Asian Pacific Americans. See infra notes $124-28$ and accompanying text.

56 See UCLA Study, supra note 18, at ii (noting that in Los Angeles the future size, characteristics, and impact of the Asian Pacific American electorate lacks definition at the present).

${ }^{57}$ See Petersen, Success Story, Japanese-American Style, N.Y. Times, Jan. 6, 1966, § 6 (Magazine), at 20; see also R. DANIELS, AsIAN AMERICA: ChINESE AND JAPANESE IN THE UNITED STATES SINCE 1850, at 318, 320 (1988) (noting that "[t]he unstated major premise of Petersen's argument was that Horatio-Alger-bootstrapraising was needed for success by such 'non-achieving' minorities as blacks and Chicanos, rather than the social programs of Lyndon Johnson's Great Society" and cautioning that "success always has a price, whether for the individual or for the group").

${ }^{58}$ See Success Story of One Minority Group in U.S., U.S. NEWS \& WORLD REP., Dec. 26, 1966, at 73 (stating that "[a]t a time when it is being proposed that hundreds of billions be spent to uplift Negroes and other minorities, the nation's 300,000 Chinese-Americans are moving ahead on their own-with no help from anyone else"). A more recent analysis summarizes that

[w]hile paying homage to their past tribulations, both articles praised the two Asian American minorities for overcoming their adversities through the particular strengths of their cultural backgrounds, and strongly implied that Asian Americans had finally succeeded in becoming accepted into white, middle-class society through their hard work, uncomplaining perseverance and quiet accommodation.

Suzuki, Education and the Socialization of Asian Americans: A Revisionist Analysis of the 'Model Minority' Thesis, AMERASIA J., vol. 4, no. 2, 1977, at 23, 24. 
facing a racial crisis. Similar media accounts of Asian American "success" have continued to the present. ${ }^{59}$

Some common implications of the success myth are beliefs such as (1) "Asian and Pacific Americans all look alike. They are pretty much the same people."; (2) "Asian and Pacific Americans are not discriminated against in employment. They hold good jobs and are found in all sectors of industry."; (3) "Asian and Pacific Americans do well because they go to college. Because of this, their income exceeds even that of white Americans."; (4) "Another indication of the socio-economic success of Asian and Pacific Americans is that many of them are in business for themselves and in this, they are

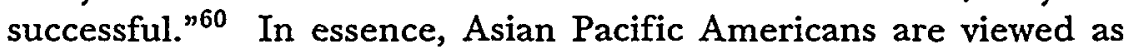
a minority group that has succeeded economically despite its minority status.

This "model minority" myth, however, amounts to just an ethnic stereotype; it characterizes all Asian Pacific Americans as quiet, obedient, and non-adversarial yet economically successful minorities. One of the myth's most dangerous fallacies is that it portrays Asian Pacific Americans as either choosing not to participate in politics or of not needing political empowerment. ${ }^{61}$ It is interest-

59 See, e.g., Chin, Foltz, Junkin, Kasindorf, Shapiro \& Weathers, Asian-Americans: A 'Model Minority,' NEwSWEEK, Dec. 6, 1982, at 39 (noting that '[a]lthough they still constitute only 1.5 percent of Americans, Asians already are far more influential than their numbers, scorning the label of a 'model minority' even as they put the bulk of their efforts into working hard to prosper"); Coleman, Probing School Success of Asian-Americans, N.Y. Times, Sept. 11, 1990, at $\mathrm{Cl}$, col. 2 (seeking to explain the "dazzling" academic performance of Asian-American students).

${ }^{60}$ See Cabezas, Disadvantaged Employment Status of Asian and Pacific Americans, in U.S. COMM'N ON CIVIL RIGHTS, CIVIL RIGHTS ISSUES OF ASIAN AND PACIFIC AMERICANS: MYTHS AND REALITIES 434, 435, 439, 442 (1979) [hereinafter MYTHS AND REALITIES].

61 For example, Justice Powell's dicta in Regents of Univ. of Cal. v. Bakke, 438 U.S. 265 (1978), suggests that Asian Pacific Americans do not need to be included in affirmative action programs. See Bakke, 438 U.S. at 309 n.45 (stating that the University's inclusion of Asian Americans for preferential treatment "is especially curious in light of the substantial numbers of Asians admitted through the regular admission process").

Many institutions of higher learning adhere to this mistaken notion, while ironically, discriminatory quotas are used against qualified Asian Pacific American high school students in the college admissions process. See Note, Assuring Equal Access of Asian Americans to Highly Selective Universities, 98 YALE L.J. 659 (1989) (outlining discriminatory ceilings on Asian American candidates to selective colleges and suggesting a possible equal protection basis for legal action); see also Asian Am. Law Students' Ass'n, Report of the Boall Hall Asian American Special Admissions Research Project, AMERASIA J., vol. 5, no. 1, 
ing to note that most "proponents" of the success model are either non-Asian scholars or reporters of the mass media, ${ }^{62}$ while critics of the model are scholars of Asian ancestry or representatives of government agencies, such as the U.S. Commission on Civil Rights. ${ }^{63}$ As one study observes, "[i]mplicit in the success theme are three crucial political messages": the "benefit denying function," the "system preserving function," and the "minority blaming function." 64 The "model minority" theory, then, is largely a myth to preserve existing inequalities and is unsubstantiated by the facts. ${ }^{65}$

1978, at 21 (arguing for the inclusion of Asian Americans in Boalt's affirmative action program); Page, Asian Americans Can't be Dismissed as a "Model" Group, Chicago Tribune, Apr. 19, 1989, $\$ 1$, at 21, col. 1 (noting University of California at Berkeley's concession that its undergraduate admissions policy shift in 1984 "reduced the importance of high school grades and increased the importance of verbal achievement test scores ... [which] 'indisputably had a disproportionate impact' on Asian Americans"). Page criticizes the conservatives' and the media's utilization of the "model minority" stereotype to discriminate against Asian Americans. He observes further that "the media too often ignore[s] the problems of disadvantaged Asians, perhaps because they fail to fit neatly into our stereotype of Asians as the 'model minority' .... Old stereotypes die hard, especially when they are convenient to an ideological point of view." Id.

62 See supra notes 57-59 and accompanying text.

63 See CALIFORNIA AdVISORY COMM'N, ASIAN AMERICANS AND PACIFIC PEOPLES: A CASE OF MISTAKEN IDENTITY (1975) (portraying the experiences of Asian Pacific Americans differently from the stereotypes held by the majority of society, and examining areas in which Asian Pacific Americans encounter significant problems); U.S. COMM'N ON CIVIL RIGHTS, SUCCESS OF ASIAN AMERICANS: FACT OR FICTION? (1980) (refuting the prevailing stereotype of Asian Pacific Americans as a successful minority); Kim \& Hurh, Korean Americans and the "Success" Image: A Critique, AMERASIA J., vol. 10, no. 2, 1983, at 3, 4; Suzuki, supra note 58, at 23.

64 See Kim \& Hurh, supra note 63, at 7 (stating that "[i]n this context, Asian American achievement was explicitly contrasted to black Americans in the 1960 s when black urban unrest was at its height and the civil rights movement was gaining momentum").

${ }^{65} \mathrm{Kim}$ and Hurh examine the case of Korean immigrants as an example and argue that Koreans are segregated in "the American labor market and mainly restricted to inferior occupations or unfavorable work conditions." Id. at 15. They maintain that "Asian Americans are generally excluded from full participation in the broader society despite their success image." Id. at 17.

A complete examination of the Koreans' situation reveals that despite high levels of education, Asian Pacific Americans are segregated in the labor market. Accepting the success image uncritically thus leads to:

1) the exclusion of Asian Americans from social programs both by public and private agencies, 2) the concealment of Asian American underemployment, 3) the reinforcement of an allegedly open social system, and 4) the 'blame the victim' approach, i.e., placing the onus of underachievement upon minorities themselves rather than finding 
Furthermore, as the study of Asian Pacific American voting patterns in San Francisco observes, although Japanese Americans generally have higher socio-economic indices, including the highest percentage of English speakers, the highest education levels, and the highest income of all Asian Pacific American subgroups, their voter registration rate is still no higher than that of the Chinese Americans. ${ }^{66}$ The San Francisco study thus suggests that the greater factor for the low political participation by Asian Pacific Americans stems from the "impact of race, culture, and responses to discrimination [which] may be affecting both Chinese and Japanese Americans and discouraging them from registring [sic] to vote." ${ }^{.17}$ In fact, the San Francisco study notes that a rise in "Chinese Americans' income levels ... do[es] not seem to be the main determinant[] of political participation," 68 although a low level of income has some impact since "when survival is the first priority, political participation becomes unimportant." ${ }^{\text {69 }}$ The study further observes that "foreign born" status and limited English ability, and not ethnic identity, contribute to low voter registration rates among Chinese Americans. ${ }^{70}$

Historical evidence, moreover, does not support the claim that Asian Pacific Americans are culturally averse to politics. Asian Pacific American history is replete with instances of collective efforts to combat common experiences of discrimination and exclusion. ${ }^{71}$ This tradition of political unification and protest is

fault with the system.

Id.

Nevertheless, the debate concerning the success theory offers another perspective on racial-ethnic relations-that "high educational achievement and related human capital resources are not sufficient to overcome the disadvantaged position of minority groups in the American labor market." Id.

One commentator also argues that Asian Americans face unique obstacles in the quest to gain parity in the legal community. See Quan, Asian Americans and Law: Fighting the Myth of Success, 38 J. LEGAL EDUC. 619, 620-28 (1988). Such obstacles include a history of discrimination, inherent biases in the system, conflicting values, ignorance about Asian Americans' possible roles, and a lack of support.

${ }^{66}$ See G. Din, supra note 18 , at 85.

${ }^{67} \mathrm{Id}$.

$68 I d$. at 84 . Note that high income levels may reflect higher rates that result from two or more wage earners per family, or extra hours worked, and not necessarily higher wages per person per hour worked.

${ }^{69} I d$. at 82.

${ }^{70}$ See id. at $83-84$.

71 The earliest acts of anti-Asian discrimination and violence in the late 
presently evident in the Asian Pacific Americans' fight against increasing anti-Asian violence, ${ }^{72}$ against quotas in university admissions, ${ }^{73}$ for inclusion in affirmative action programs, ${ }^{74}$ for Japanese American reparations, ${ }^{75}$ for immigration reforms, ${ }^{76}$ and for access to the ballot. ${ }^{77}$

Finally, socio-cultural theories also dismiss the history of institutional discrimination faced by Asian Pacific Americans, denying responsibility for their present situation and serving a "minority blaming function." 78 These theories do not recognize subtle exclusionary barriers faced by Asian Pacific Americans attempting to enter the political process, and ignore the history of arbitrary exclusion and racial attacks against the entire group if any individual or subgroup "made trouble."79

1800s instigated collective Asian Pacific American protest and activism. For example, Chinese railroad workers staged strikes to demand wages and conditions equal to those of white workers. Asian Pacific Americans also fought collectively against racial school segregation in San Francisco. See G. Din, supra note 18 , at 18-19.

72 See JAPANESE AMERICAN CHIZENS LEAGUe, A REPORT ON ANTI-ASIAN VIOLENCE IN THE UNITED STATES 1-10 (1985); Victory in Anti-Asian Violence Case of Police Brutality, OUTLOOK, Spring 198\%, at 1, col. 2; Let Your Voices Be Heard!, Asian Week, Sept. 8, 1989, at 2.

${ }^{73}$ See Nakanishi, A Quota on Excellence? The Asian American Admissions Debate, CHANGE, Nov./Dec. 1989, at 39; DeWitt, supra note 6, at B9, col.1; Johnson, supra note 6 , at $A 1$, col.2.

${ }^{74}$ See Report of the Boalt Hall Asian American Special Admissions Research Project, supra note 61 , at 21 .

${ }^{75}$ See Nakanishi, Seeking Convergence in Race Relations Research, Japanese-Americans and the Resuryection of the Internment, in ELIMINATING RACISM 159 (P. Katz \& D. Taylor eds. 1988); Redress Becomes Law, supra note 6, at 1.

76 See AALDEF Calls Immigration Bill Unfair, OUTLOOK, Spring 1989, at 5; AALDEF Prepares Community for New Immigration Law, OUTLOOK, Spring 1987, at 1.

${ }^{77}$ See Boyarsky, Redistricting Drama in the Back Rooms, L.A. Times, Dec. 14, 1990, at B2, col. 1; Gross, supra note: 8, at A22, col. 1; Ridgeway, California Dreamin': Asian Americans Suffer a Political Wipeout, Village Voice, May 31, 1988, at 16-17.

${ }^{78}$ See supra note 64 and accompanying text.

79 For example, perpetrators of anti-Asian violence never attempted to determine the nationality of the Asian Pacific American victim. All Asian Pacific Americans were vulnerable to the hatred and systematic exclusion directed against the Chinese coolie laborers, against Filipino migrant workers, and against Japanese American internment victims. The recent Japanbashing sentiment has also motivated many acts of anti-Asian violence, including the notorious murder of Vincent Chin, a Chinese American auto worker in Detroit. Chin's attackers, two laid-off auto workers, believed that Chin was Japanese and "allegedly blamed him for the layoffs in the industry." U.S. COMM'N ON CIVIL RIGHTS, RECENT ACTIVITIES AGAINST CITIZENS AND RESIDENTS OF ASIAN DESCENT 43 (1986). 
On the other hand, AALDEF's analyses of its exit polls offer a more realistic assessment of the factors that forge the political habits of Asian Pacific Americans. The AALDEF polls revealed "that most Asian Americans who vote are long-time citizens, American-born, or very familiar with American customs and the language." ${ }^{80}$ The exit polls also suggested that immigrants who have only recently become citizens and those who "feel that their needs will not be represented by non-Asian candidates" often do not vote. ${ }^{81}$ Furthermore, $20 \%$ stated that they were " $n$ ot very fluent' in English," and 74\% said they were only "moderately fluent." 82 Most significantly, $71 \%$ said they would vote more often "if more Asian candidates ran for office." 83

\section{Past Legal Barriers to Effective Political Participation}

\section{A. History of Formal Racial Discrimination}

\section{Legal Exclusion}

Asian Pacific Americans encountered formal racial discrimination since the beginning of Asian immigration in the mid-1800s $\mathrm{s}^{84}$

${ }^{80}$ Getting Out the Vote, supra note 42 , at 1 . Such a characterization presumably can be made about any immigrant group. It must be remembered, however, that although Asian immigration started in the mid-19th century, exclusionary laws precluded Chinese immigrants from gaining citizenship status until 1943 and Japanese immigrants until 1952.

81 Id. at 1-2.

82 Id. at 1. A majority of the Asian Pacific Americans polled after New York City's 1989 mayoral election also stated that "they preferred bilingual ballots." AALDEF Surveys Asian Voters, supra note 43, at 3.

${ }^{83} I d$. at 2 (emphasis added).

84 The first wave of Asian immigrants came from Southern China where peasant rebellions and the crumbling Manchu Dynasty put the country in chaos. The western expansion in the United States had a "pull" factor with its need for labor on the railroads, in manufacturing, in fishing, and in the canning industries. In response, young Chinese bachelors came in great numbers under contract labor mechanisms. This cheap labor clashed with white union workers as the United States suffered through a depression in the 1870s. The Chinese workers became easy scapegoats for the economic problems, and the consequent anti-Asian violence and legislation culminated in the Chinese Exclusion Act of 1882, the first exclusionary immigration law on the basis of race. See Hune, U.S. Immigration Policy and Asian Americans: Aspects and Consequences, in MYTHS AND REALITIES, supra note 60, at 283, 284-85; Mei, Socioeconomic Origins of Emigration: Guangdong to Califormia, 1850-1882, in LABOR IMMICRATION UNDER CAPITALISM: ASIAN WORKERS IN THE UNITED STATES BEFORE WORLD WAR II 219-47 (L. Cheng \& E. Bonacich eds. 1984) [hereinafter LABOR IMMIGRATION UNDER CAPITALISM]. 
when exclusionary laws were enacted to keep the "undesirables" from entering the United States and from becoming American citizens. ${ }^{85}$ As one scholar highlights, two factors historically influenced the formulation of United States policy toward Asian immigration, racism and foreign policy. ${ }^{86}$

Not only were Asian immigrants unable to become naturalized citizens, ${ }^{87}$ but Congress even attempted to deny citizenship status to American-born Asians: "the citizenship status of Asians born in the United States was unsettled until . . . an American-born Chinese successfully tested his right to be an American citizen before the United States Supreme Court." 88 The alien status of Asian Pacific Americans prohibited them from securing the rights and protections of the Constitution. For over 150 years, discriminatory legislative actions by Congress and state governments succeeded in excluding Asian immigrants from gaining any kind of a foothold in American society.

"The two most pervasive and damaging restrictions imposed upon Asians in America were bars to owning or leasing land and limitations on employment opportunities." 89 California and other

${ }^{85}$ See Hune, supra note 84 , at 285 . Chinese exclusionary laws became more restrictive with every renewal until their eventual repeal in 1943 . See id. The same sequence-recruitment of cheap labor, entry of young single men, and increasing competition, hostility, legislation, and violence against the particular group-characterizes all early Asian immigration, including that of the Japanese in the late 1800s and of the Filipinos after the Philippines' independence in 1898. See Bonacich, Some Basic Facts: Patterns of Asian Immigration and Exclusion, in LABOR IMMIGRATION UNDER CAPITALISM, supra note 84, at 60-77; Mei, Asian Immigrant Workers and Communities, in LABOR IMMIGRATION UNDER CAPITALISM, supra note 84 , at 359-69.

80 Hune asserts that the historic policy was one of racism, discrimination, and victimization for the purpose of carrying forward specific domestic and foreign policies. See Hune, supra note 84, at 283-91.

87 See Kim \& Kim, Asian Immigrants in American Law: A Look at the Past and the Challenge Which Remains, 26 AM. U.L. REv. 373, 373-407 (1977) (surveying Asian Pacific Americans' fight for equality and the remaining issues concerning the legal status of Asian immigrants); Lesser, Always "Outsiders": Asians, Naturalization, and the Supreme Court, AMERASIA J., vol. 12, no. 1, 1985-86, at 83, 83-97 (outlining immigration and naturalization cases and noting a trend of racial legal reasoning that might continue in future cases).

Kim and Kim note that the Supreme Court has upheld the exclusion of Asians in statutory immigration laws as a valid exercise of congressional power. See Kim \& Kim, supra, at 377-79.

${ }^{88} \mathrm{Kim} \& \mathrm{Kim}$, supra note 87 , at 379 (citing United States v. Wong Kim Ark, 169 U.S. 649 (1898)).

${ }^{89}$ Id. at 381; see also Elway', Presentation of Rita Fujiki Elway, in MYTHS AND REALITIES, supra note 60, at 106, 107 (discussing the impact of legislative 
states erected alien land laws to restrict Asian American land ownership. ${ }^{90}$ The first comprehensive alien land statute, passed by California in $1913,{ }^{91}$ prohibited full real estate ownership by any aliens not "eligible for citizenship under the laws of the United States." 92 This statute became the prototype for similar laws in many states which were in effect until the McCarran-Walter Act of 1952 finally granted Asian immigrants eligibility for citizenship. ${ }^{93}$

Employment discrimination against Asian Pacific Americans through acts and ordinances promulgated under the guise of protections for health, safety, and social welfare was also prevalent. Although the Supreme Court overturned some discriminatory ordinances, ${ }^{94}$ special licensing requirements for many professions precluded Asian aliens from entering these professions and from earning a living. ${ }^{95}$ Moreover, unequal taxation was imposed on Asian Pacific Americans. ${ }^{96}$ Anti-miscegenation laws prohibiting

barriers to land ownership on political participation by the Asian/Pacific community).

${ }^{90}$ See Hocking, Asian-Americans and the Law, in POLITICAL PARTICIPATION, supra note 15, at 166, 171-72; Kim \& Kim, supra note 87, at 381 .

91 See 1913 Cal. Stat. 206, ch. 113, §§ 1-2; Kim \& Kim, supra note 87, at 381.

$92 \mathrm{Kim} \& \mathrm{Kim}$, supra note 87 , at 320 n.92. Since the U.S. naturalization laws at that time defined those eligible for citizenship as "all free White persons and persons of African nativity or descent, ${ }^{n}$ these land laws were specifically directed at Asian immigrants. See Hocking, supra note 90, at 171 (citing Hidemitsu Toyota v. United States, 261 U.S. 264 (1923)). Hence, the 1913 California statute subjected the real estate ownership rights of Asian Pacific Americans to "treat[ies] now existing between the government of the United States and the nation or country of which [the Asian Pacific American] was a citizen or subject ....” 1913 Cal. Stat. 206, ch. 113, § 2.

93 See Hocking, supra note 90, at 171 (noting that Arizona, Louisiana, New Mexico, Idaho, Montana, and Kansas based their land statutes on the 1913 California Alien Land Law, while Washington and Oregon had laws restricting land ownership since 1906).

94 See, e.g., Yick Wo v. Hopkins, 118 U.S. 356 (1886) (invalidating a facially neutral California ordinance because it arbitrarily discriminated against Chinese Americans in the way it was administered).

95 For instance, state licensing requirements foreclosed non-citizen Asian Pacific Americans from becoming attorneys, physicians, teachers, pharmacists, veterinarians, hairdressers, cosmetologists, barbers, funeral directors, peddlers, and hunters. See Kim \& Kim, supra note 87, at 386 n.76. In addition, federal regulations limited job opportunities in the civil service to American citizens, thus excluding Asian Pacific Americans. See id. at 386.

96 Asian immigrants had to pay special "foreigner" taxes in California such as the Foreign Miners' License Tax, a special monthly fishing tax, and a special monthly "police" tax that was supposed to protect white labor from altercations with Chinese "coolie" labor. See Hocking, supra note 90, at 173. 
interracial marriage with Asian Pacific Americans also hindered inclusion in mainstream American society. ${ }^{97}$

In addition to the denial of citizenship status and the specific anti-Asian legislation, a myriad of invidiously discriminatory legislation that affected those who were not "free white persons" in general also targeted Asian Pacific Americans. ${ }^{98}$ Such racist legislation and court rulings "set the stage for the World War II internment of Japanese Americans and subsequent Supreme Court decisions defending its constitutionality." astutely observes that Japanese American internment was not a product of war hysteria and racism as commonly alleged, but rather, a predictable result of the predominant legal reasoning concerning Asian Americans at that time. ${ }^{100}$ The turning point for Asian Pacific Americans' "struggle for equal rights" was the Immigration and Nationality Act of $1952^{101}$ which finally eliminated the provision against naturalization of "nonwhite aliens."102 Their newly gained citizenship status finally freed Asian Pacific Americans from restrictions to societal participation based on citizenship.

Nevertheless, attempts to keep Asian Pacific Americans "in their place" did not stop. Pursuant to the model minority theme and citing the high education and income levels of some visible Asian Pacific Americans, many praised Asian Pacific Americans for their "success" while dismissing their problems and needs as cured and nonexistent. Many Asiar Pacific Americans themselves welcomed such appraisals as preferable to being labeled as undesirable

97 See id. at 176. The Supreme Court struck down such laws in Loving v. Virginia, 388 U.S. 1 (1967). Flowever, as of 1972, some states, such as Georgia, still had anti-miscegenation law's. See id.

98 For example, legal segregation based on race applied to Asian Pacific Americans as "nonwhites," and Asian Pacific Americans were also not allowed to testify in courts. See, e.g., Fong Yue Ting v. United States, 149 U.S. 698, 72930 (1893) (upholding $\S 6$ of the May 5, 1892 congressional Act requiring Chinese laborers to prove residency "by at least one credible white witness").

99 Lesser, supra note 87 , at 83 . These subsequent cases were Korematsu v. United States, 323 U.S. 214 (1944) (upholding the exclusion order imposed upon Japanese Americans), Hirabayashi v. United States, 320 U.S. 81 (1943), and Yasui v. United States, 320 U.S. 115 (1943) (upholding curfew orders that restricted travel by Japanese Americans during World War II).

${ }^{100}$ See Lesser, supra note 87 , at $92-94$.

${ }^{101}$ Pub. L. No. 82-414, 66 Stat. 163.

102 See Kim \& Kim, supra note 87, at 390. But even as recently as 1990, Congress has entertained restrictive bills such as the Kennedy-Simpson Immigration Bill to limit A.sian and Hispanic immigration to the United States. See AALDEF Warns About New Asian Exclusion Act, OUTLOOK, Summer 1990, at 4. 
aliens. ${ }^{103}$ But in fact, exclusion had just assumed a different veneer. The success image led to the exclusion of Asian Pacific Americans from many minority aid programs that resulted from the civil rights movement. ${ }^{104}$ Underemployment replaced unemployment, and many Asian Pacific Americans holding advanced degrees were forced into the leftover, menial, service sector jobs or small family businesses. At the same time, the second mechanism for excluding Asian Pacific Americans from American society-that of anti-Asian violence-gained renewed momentum. The 1980s witnessed increasing hostility and violent crimes directed against Asian Pacific Americans as popular perceptions of the successful Asians taking away American jobs, land, and resources exacerbated racial tensions. ${ }^{105}$

Thus, throughout American history, Asian Pacific Americans were systematically excluded from participating fully in society and were relegated to those roles for which they were allowed to enter the United States in the first place-that of providing cheap labor.

\section{Voting Rights and Asian Pacific American Disfranchisement}

Until the mid-twentieth century, Asian Pacific Americans were effectively disfranchised as nonwhites, noncitizens, and non-English speakers, and thus could not participate in electoral politics to represent their interests. As noncitizens, Asian Pacific Americans did not have the right to vote in any election, and even Asian citizens were ineligible to vote in many states. ${ }^{106}$ Thus excluded from having any say in elections and in legislative decisionmaking, Asian Pacific Americans could not procure resources for themselves, secure effective representation, or voice their interests. ${ }^{107}$

103 For an example of such assessments of Asian Pacific American "success," see Ueda, supra note 10, at 16.

${ }^{104}$ See Okura, Equal Rights and Equal Opportunities, in MYTHS AND REALITIES, supra note 60, at 722, 722-23; Wang, Statement of L. Ling-chi Wang, Assistant Professor, University of Califormia, Berkeley, in MYTHS AND REALITIES, supra note 60, at 40,43-44.

105 See JAPANESE AMERIGAN CIrIZENS LEAGUE, supra note 72, at 5, 8; U.S. COMM'N. ON CIVIL RIGHTS, supra note 79, at 40-56.

106 See, e.g., CAL. CoNST. art. II, $\S 1$ (1849, revised 1879, amended 1911) (denying Chinese natives the eligibility to vote). California became the leader of anti-Asian directives as it responded to the increasing numbers of Asian immigrants residing within its borders. Soon the anti-Asian sentiment became a national phenomenon as popular perceptions of the evil "chinks" and dirty "orientals" spread through political campaigns, the media, and education.

${ }^{107}$ See Presentation of L. Ling-chi Wang, Assistant Professor, Asian American Studies, 
In sum, socio-cultural explanations do not account for the whole story and divert attention from the true nature of the problem. Problems relating to Asian Pacific Americans gaining equal participation in all aspects of American society are more complicated and include their immigrant status, their diverse nationalities and cultural backgrounds, lack of knowledge of their group history and common ground, and the majority's efforts to pit them against other minority groups.

\section{Current Barriers to Effective Political Participation}

Although a closer examination of the socio-cultural explanations for Asian Pacific American political inactivity reveals many fallacies in the theories and indicates that Asian Pacific Americans have not been, and are not being, incorporated into the political process, case law concerning Asian Pacific American vote dilution or other barriers to the franchise is almost nonexistent. That neither the Asian Pacific American community nor the Justice Department has been able or willing to initiate legal challenges to the systematic exclusion of Asian Pacific Americans from the political process is itself a powerful indicator of the lack of Asian Pacific American political participation. ${ }^{108}$ Reasons for the absence of litigation in this area can be gleaned from an examination of the available vote dilution case law concerning both racial and language minorities.

University of California, Berkeley, in MYTHS AND REALITIES, supra note 60, at 21, 25 (pointing out that the "conspicuous absence of Asian Americans on Federal commissions, boards, councils, advisory committees ... task forces ... staffs ... [and] agencies effectively render[s] the Asian American community ineligible for needed resources and services"). In fact,

[the] observable consequence of exclusion from government to the minority communities ... has been (1) fewer services from government agencies, (2) failure to secure a share of local government employment, (3) disproportionate allocation of funds, location and type of capital projects, (4) lack of equal access to health and safety related services, as well as sports and recreational facilities, (5) less than equal benefit from the use of funds for cultural facilities, and (6) location of undesirable facilities, e.g., garbage dumps, or dog pounds, in minority areas.

H.R. REP. NO. 227, 97th Cong., lst Sess. 14 (1981).

108 An exception is the Los Angeles redistricting case in which Korean American intervenors joined as plaintiffs against the county. See United States v. City of Los Angeles, No. CV 85-7739 (C.D. Cal., settled Oct. 10, 1986). 


\section{A. Modern Vote Dilution}

In addition to legislative action such as the Voting Rights Act of 1965 and its subsequent amendments, the Supreme Court has, at least recently, constitutionally guaranteed minority access to the ballot. Voting and registration restrictions based on race have been judicially and legislatively invalidated and other more ingenious ways to keep "nonwhites" from the voting booth have also been declared void. ${ }^{109}$ Some scholars still argue that the right to vote equals the right to cast a ballot, and that the right was achieved when direct barriers to casting ballots were eliminated. ${ }^{110}$

The Voting Rights Act, as amended in 1982, however, implies a broader view of the right to vote. As the Senate Report discussing the 1982 amendments noted, "the political effectiveness of minority groups" has been hampered by new and more sophisticated methods of impeding minority "access to the ballot box"; ${ }^{111}$ these methods fall under the umbrella term of "minority vote dilution." 112 Vote dilution, as recognized and specifically prohibited by section 2 of the Voting Rights Act, is the submergence of a minority group's voting strength and the denial of an equal

109 See, e.g., Oregon v. Mitchell, 400 U.S. 112 (1970) (holding that Congress could prohibit the use of literacy tests during elections because such tests discriminated against voters on account of their race); Kramer v. Union Free School Dist., 395 U.S. 621 (1969) (holding that state statutes selectively granting the right to vote to certain residents must be sufficiently tailored to further a compelling state interest); Harper v. Virginia Bd. of Elections, 383 U.S. 663 (1966) (finding that state poll taxes are invalid conditions on the right to vote); Reynolds v. Sims, 377 U.S. 533 (1964) (establishing the oneperson-one vote rule); Smith v. Allwright, 321 U.S. 649 (1944) (utilizing the state action doctrine to find primaries limited to the white electorate unconstitutional); Guinn v. United States, 238 U.S. 347 (1915) (invalidating a grandfather clause of a voting rights amendment to the state constitution).

110 See A. Thernstrom, Whose Votes Count?: AfFirmative Action AND MINORITY VOTING RIGHTS 238-44 (1987).

${ }^{111}$ See S. REP. No. 417, 97 th Cong., 2d Sess. 28, 29, reprinted in 1982 U.S. CODE CONG. \& ADMIN. NEWS 177, 205.

${ }^{112}$ See MiNORITY VOTE DILUTION 4 (C. Davidson ed. 1984). Davidson describes vote dilution as a "process whereby election laws or practices, either singly or in concert, combine with systematic bloc voting among an identifiable group to diminish the voting strength of at least one other group." Minority vote dilution, specifically, is defined as a situation where "the voting strength of an ethnic or racial minority group is diminished or canceled out by the bloc vote of the majority." He continues, noting that "[i]n extreme cases, minority vote dilution results in the virtual exclusion of one or more groups from meaningful participation in a political system." Id. 
opportunity to participate in the political process caused by discriminatory mechanisms or practices. ${ }^{113}$

The Supreme Court first construed and applied the amended section 2 of the Voting Rights Act in Thomburg $v$. Gingles. ${ }^{114}$ The plaintiffs, a group of black registered voters in North Carolina, claimed that the 1982 redistricting scheme by the North Carolina General Assembly 'impaired black citizens' ability to elect representatives of their choice in violation of the . . Constitution and of $\S 2$ of the Voting Rights Act." I15 In affirming the lower court's holding for the plaintiffs, the Court emphasized that "[m]inority voters who contend that the multimember form of districting violates $\S 2$ must prove that the use of a multimember electoral structure operates to minimize or cancel out their ability to elect their preferred candidates."116 The plaintiffs must thus demonstrate a causal relationship between the challenged electoral scheme and the submergence of their voting power in a white majority. ${ }^{117}$

According to the Court, the most relevant of the Senate Report factors in assessing a section 2 claim were those that helped to evaluate the situation from a "functional" view of the political process. ${ }^{118}$ From this evolved a three-prong test as a section 2 liability threshold. The plaintiff must demonstrate that: (1) the minority group is geographically compact with sufficiently large numbers "to constitute a majority in a single-member district," (2) that there is political cohesion within the group as demonstrated by distinctive interests and blo: voting, and (3) that there is sufficient

${ }^{113}$ See 42 U.S.C. $\$ 1973 \mathrm{~b}(\mathrm{~b})(1988)$.

114478 U.S. 30 (1986).

115 Id. at 35 . The essence of the plaintiffs' claim was that the state-wide redistricting plan that used multimember districts diluted their voting strength, by impairing a substantial number of black voters from electing candidates of their choice. See id. at 46 . For instance, the Court pointed out that while blacks constituted $22.4 \%$ of the population, only two to four percent of the State Senate was black. Id. at 40 .

116 Id. at 48 .

117 See id.

${ }^{118}$ See id. at 48 n.15. The Court stated that

under a "functional" view of the political process mandated by $\S 2$, ... the most important Senate Report factors bearing on $\$ 2$ challenges to multimember districts are the "extent to which minority group members have been elected to public office in the jurisdiction" and the "extent to which voting in the elections of the state or political subdivision is racially polarized."

Id. (citation omitted). 
racial bloc voting by the majority that operates "usually to defeat the minority's preferred candidate."119

The Court's interpretation of section 2 in Gingles was criticized as requiring a form of proportional representation, a right "to elect as many representatives under a multimember district as (the minority group) could elect under the most favorable single-member district scheme." 120 Justice O'Connor argued that this approach was rejected by Congress when section 2 was passed. ${ }^{121}$ Others regret that the Court in Gingles limited its analysis of the political process to electoral rights, ${ }^{122}$ and that Gingles led lower courts to treat racial vote dilution as "simply a geographic phenomenon." ${ }^{123}$ In that light, an examination of the Asian Pacific Americans' inability to attain political equality helps to demonstrate the weaknesses in the Gingles approach to minority representation cases.

From the perspective of Asian Pacific Americans, the main difficulty with the Gingles approach lies in the first prong of the liability threshold, which requires geographic compactness of the minority group. This first prong assumes the virtues of residential concentration because most section 2 vote dilution claims challenge multimember districts or at-large elections. However, when the minority group is not concentrated enough to form a single-member district, the obsessive focus on geography becomes misplaced ${ }^{124}$ and fails to protect Asian Pacific Americans, most of whom are geographically dispersed. This dispersal is often not voluntary. ${ }^{125}$

119 Id. at 50-51.

${ }^{120} I d$. at $96-98$ (O'Connor, J., concurring).

121 See id.

122 See Abrams, "Raising Politics Up": Minority Political Participation and Section 2 of the Voting Rights Act, 63 N.Y.U. L. REV. 449 (1988) (arguing that the Court's interpretation of the political process was too narrow).

${ }^{123}$ Karlan, supra note 32, at 174, 203.

124 Karlan emphasizes that the goal is the "representation of people, not geographic interests." Id. at 182.

125 For instance, many Japanese American communities in California were disrupted and destroyed by the internment of Japanese Americans in camps all over the United States. Because they were forced to relinquish their land and belongings, many Japanese Americans did not have homes to which to return after their release. In fact, the government specifically appealed to the Japanese Americans not to go back to the Japanese American communities in California. In addition, recent urban renewal programs have forced many Asian Pacific Americans out of Chinatowns and other ethnic communities. The Indochinese refugees were similarly dispersed throughout the United States to lessen the burden on a particular community or state. See Delacruz, Issues and Concerns on Indochina Refugee Reseltlennent, in MYTHS AND REALTIES, supra note 60, at 215 (noting that the State Department's initial 
Thus the geographic insularity requirement does not address the problem of discrimination despite nonsegregation. ${ }^{126}$

Additionally, even in those areas of high Asian Pacific American concentration, ${ }^{127}$ Asian Pacific Americans do not comprise a majority so as to form aesthetically simple and judicially manageable single-member districts. ${ }^{128}$ Therefore, the remedy of redistricting would not cure Asian Pacific Americans' lack of an equal opportunity to participate.

The bloc voting components of the second and third prongs present further difficulties for Asian Pacific Americans in establishing the liability threshold under the Gingles approach to vote dilution claims. ${ }^{129}$ Specifically, a group's political cohesion, which is necessary to satisfy the second prong of Gingles, is most easily demonstrated by group bloc voting. ${ }^{130}$ In the absence of a clear choice such as an Asian Pacific American candidate, however, the Asian Pacific American community's political cohesion cannot be measured in this manner. ${ }^{131}$

plan called for an even distribution of Indochinese refugees across the country).

126 Some lower court vote dilution cases interpreting the Gingles standard have focused exclusively on geography. See, e.g., McNeil v. Springfield Park Dist., 851 F.2d 937 (7th Cir. 1988); Gomez v. City of Watsonville, 863 F.2d 1407 (9th Cir. 1988); Potter v. Washington County, 653 F. Supp. 121 (N.D. Fla. 1986). In contrast, Dillard v. Baldwin County Bd. of Educ., 686 F. Supp. 1459 (M.D. Ala. 1988), adopted the functional approach to the political process that had been endorsed in the Senate Report on the 1982 amendments. See supra note 118 and accompanying text.

127 The three metropolitan areas examined in this Comment-Los Angeles, San Francisco, and New York-are good examples.

128 The few exceptions, such as New York City's Chinatown area, have been "gerrymandered between two congressional districts, making it difficult for Chinese Americans to have much impact even when they do vote in large numbers." Getting Out the Vote, supra note 42, at 2; see also ASIAN AMERICANS: AN AGENDA FOR ACTION, supra note 31, at 40 (stating that "[e]ven Chinatown, which has the largest concentration of Asian Americans, is not able to attain its political potential because of the configuration of the various election districts").

129 See supra text accompanying note 119.

${ }^{130}$ See Gingles, 478 U.S. at 56.

131 The problematic lack of political participation by Asian Pacilic Americans, see supra notes $19-31$ and accompanying text, and its consequent dearth of Asian Pacific American political candidates, see supra notes 32-38 and accompanying text, make it difficult to measure bloc voting either by the Asian Pacific American group voting for its preferred candidates or by the majority voting against the group's choice. The focus on polarized voting patterns will thus not provide any insights into the problems of Asian Pacific American vote dilution. 
Nevertheless, there is ample evidence to demonstrate that, in other respects, Asian Pacific Americans are politically cohesive and therefore can meet the second prong requirement of Gingles. Not only do they more readily identify with Asian Pacific American candidates, ${ }^{132}$ but they share an ever-increasing number of common interests and needs distinctive to the group. ${ }^{133}$ Furthermore, to counter the indiscriminate anti-Asian directives, from both the populace and the legislature, Asian Pacific Americans have learned to build and utilize an Asian Pacific American collective.

Similarly, there is evidence (other than bloc voting) suggesting that the majority population "usually" votes to defeat Asian Pacific American candidates; this would satisfy the third prong of Gingles. ${ }^{134}$

\section{B. Disfranchisement by Unremedied Language Barriers}

In addition to the indirect dilution of Asian Pacific Americans' voting power, a persistent direct barrier for Asian Pacific Americans is their status as language minorities. Although the 1975 amendments to the Voting Rights Act "broadened the 1965 law to include the issue of discrimination against 'citizens of language minorities' and banned practices denying the right of any citizen of the United States to vote" because of her language minority status, ${ }^{135}$ empir-

132 See Getting Out the Vote, supra note 42, at 2.

133 See supra notes 71-77 and accompanying text.

${ }^{134}$ See Lu, Ex-Alhambra Mayor Aids Drive to Start Asian Political Committee, L.A. Times, Feb. 2, 1989, at 1, col. 1 (describing a twice defeated Asian American candidate to the city council who attributes his defeats to prejudice among white voters, who, upon being asked for votes, said "they were not going to support an Asian"). In the town of Monterey Park, the growth of the Asian population from $14 \%$ to $40 \%$ during the 1970 s triggered a white backlash. As a result,

[t]he city council-including its only Chinese member, Lily Chen-was pictured as the pawn of Chinese developers and pushed out of office.

A reform council voted a moratorium on new construction of residential and some commercial buildings. The moratorium was followed by a city resolution supporting English as the nation's official language. The new council asked the police department to assist the federal Immigration and Naturalization Service in ferreting out illegal aliens. Meetings of the city council grew bitter, and Monterey Park became racially polarized.

Ridgeway, supra note 77, at 16.

is5 See A. Leibowitz, Federal Recognition of the Rights of Minority LANGUAGE GROUPS 6 (1982); see also H.R. REP. No. 227, supra note 107, at 23-28 (outlining the basis for enactment of the language minority provisions and reasons for their continuance by the 1982 amendment). Noting that evidence 
ical evidence demonstrates that non-English speaking Asian Pacific Americans have remained effectively disfranchised. For example, the UCLA study of Asian Facific American voter registration in the Los Angeles county area reveals that

26.7\% of all Asian Pacific Americans eighteen years and older, and therefore of voting age, in Los Angeles county in 1980 indicated that they did not speak English well or not at all; and in every city or Asian Corridor area which was surveyed, Asian Pacific Americans had a higher proportion of such individuals than their local communities. ... [But] [n]o city or area in Los Angeles county has ever had Asian language electoral materials, be they for election purposes or encouraging individuals to register to vote. ${ }^{136}$

The analysis of San Francisco's voter registration data also shows that low registration rates among Chinese Americans are partly caused by being born in a foreign country, but more importantly, are caused by their lack of English skills. ${ }^{137}$ In New York, the AALDEF's exit poll showed that $83 \%$ of those who said they were not fluent in English would vote more often if bilingual ballots were available. ${ }^{138}$ This data demonstrates the existence of "de facto discrimination that is in part a product of their [Asian immigrants'] unfamiliarity with the language and ways of their new country." 139

indicated a need for the extension of language minority provisions, the Committee concluded that "[1]anguage assistance is provided to address the vestiges of voting discrimination against language minority citizens and is an integral part of providing the protections which the Act has sought to extend to all minorities." Id. at 28.

${ }^{136}$ UCLA Study, supra note 18, at 12-13.

197 See G. Din, supra note 18, at 2; see also Loo, The 'Biliterate' Ballot Controversy: Language Acquisition and Cultural Shift Among Immigrants, 19 INT'L MIGRATION REV. 493,497 (1985) (finding that $70 \%$ of workers in San Francisco's Chinatown were Chinese-speaking or Chinese language dominant).

${ }^{138}$ See Getting Out the Vote, supra note 42, at 1 . Although it is estimated that at least 600,000 Asian Pacific A.mericans live in New York City as of 1988, see QUEEN COLLEGE ASIAN AMERICAN CENTER, 1980 CENSUS DATA AND ESTIMATES (1988), Gail Kong of the Chinatown Voter Education Alliance points out that there are no bilingual services available in any Asian language. Furthermore, the Board of Registrar does not allow others (such as the Chinatown Voter Education Alliance) to even translate the candidates' names, and major public service agencies concerned with voter outreach such as Voter '89 are also unreachable by non-English speaking Asian Pacific Americans (their telephone number is VOTER89). Interview with Gail Kong in New York City (Oct. 24, 1989) (notes on file with author).

139 Kim \& Kim, supra note 87 , at 407 (calling for affirmative assistance for Asian immigrants entering the mainstream of American society and politics). In addition, the participants of the New York State conference on Asian Pacific American political action noted as part of their series of recommen. 
The coverage formula that triggers protection for members of a single language minority ${ }^{140}$ provides only minimal protection for non-English speaking Asian Pacific Americans. This problem, however, is not evidenced by litigation involving Asian Pacific Americans. ${ }^{141}$ Instead, cases involving non-English speaking Hispanic Americans reveal the inadequacies of the multilingual provision of the Voting Rights Act. These inadequacies are exacerbated in the case of Asian Pacific Americans because of the diverse languages spoken by the "generic" Asian Pacific American group. Thus, although Asian Pacific Americans as a group may form more than five percent of the voting age population in a jurisdiction, it is extremely difficult for one language minority (i.e., Chinese, Japanese, or Korean) to constitute five percent of the relevant population.

A Yale Law Journal Note makes a compelling Equal Protection argument that the multilingual assistance provisions of the Act are

dations, that the language minority provision of the Voting Rights Act as amended in 1975

contains a deficiency for certain small, language minority groups, including Asian Americans.... [which] should be communicated to the Federal Government. The coverage formula, as presently constituted, states that 5 percent of the citizens of voting age in a county must belong to a single language minority group. There are few counties in the United States where a single Asian subgroup constitutes 5 percent of the population of voting age. Congress should therefore further amend the Voting Rights Act of 1965 to lower the coverage formula from 5 percent to 3 percent and set the jurisdiction level from a county to a precinct.

ASIAN AMERICANS: AN AGENDA FOR ACTION, supra note 31, at 51.

${ }_{140}$ See 42 U.S.C. \$ $1973 \mathrm{aa}-1 \mathrm{a}(\mathrm{b})(1982)$. The statute states in relevant part that

no State or political subdivision shall provide registration or voting notices, forms, instructions, assistance, or other materials or information relating to the electoral process, including ballots, only in the English language if the Director of the Census determines (i) that more than 5 percent of the citizens of voling age of such State or political subdivision are menbers of a single language minority and (ii) that the illiteracy rate of such persons as a group is higher than the national illiteracy rate ....

Id. (emphasis added). "Illiteracy" is defined as "the failure to complete the fifth primary grade." $I d$.

141 When bilingual ballots were more prevalent in San Francisco's Chinatown district, the only case concerning Asian Pacific Americans as language minorities involved a government voter fraud investigation which targeted Chinese-speaking and Spanish-speaking voters requesting bilingual ballots. See Olagues v. Russoniello, 797 F.2d 1511, 1520 (9th Cir. 1986) (en banc), vacated as moot, $108 \mathrm{~S}$. Ct. 52 (1987). 
not sufficient to guarantee non-English speakers the equal right to vote and suggests solutions for Congress and the judiciary to rectify the problem. ${ }^{142}$ Disfranchisement of Asian Pacific Americans, however, is more severe than that of Spanish-speaking citizens. ${ }^{143}$ The threshold trigger figure for coverage was decided upon without an examination of the circumstances and the particular needs of Asian Pacific Americans. ${ }^{144}$ Thus many potential Asian Pacific American voters are precluded from the benefits provided by the multilingual provisions because they fail to meet the requisite numerical criteria.

Furthermore, as one scholar points out, Asian immigrants have greater difficulty learning English than Hispanic immigrants since the orthographic and language structure differences between Asian languages and the English language are greater. ${ }^{145}$ Additionally, Asian immigrants gain oral comprehension and speaking ability before reading and writing abilities (which are needed to vote and fully participate in the governing structure of society). The acquisition of writing abilities is hampered by the need to learn a completely new script. ${ }^{146}$ Because Asian Pacific Americans can often speak English long before they can read and write it, many non-English speaking Asian Pacific Americans who do not live in

142 See Note, Voting Rights and the Constitution: The Disenfranchisement of NonEnglish Speaking Citizens, 97 YAI.E L.J. 1419, 1425-27 (1988). This Note argues that the courts should apply a strict scrutiny equal protection analysis since "elections held only in English effectively deny a fundamental right of nonEnglish speakers. A State's preference in favor of English-speaking voters is, thus, unequal treatment that should trigger strict scrutiny review." Furthermore, "[b]ecause the states have chosen to facilitate the right to vote for some it is incumbent on the states to facilitate that right for all." Id. (footnotes omitted).

143 The problem of disfranchisement of Hispanic Americans as language minorities is discussed fully in $i d$.

144 The 5\% trigger figure was lifted conveniently from lower court cases involving the disfranchisement of Spanish-speaking citizens by English-only elections. See Torres v. Sachs, 381 F. Supp. 309, 313 (S.D.N.Y. 1974); Arroyo v. Tucker, 372 F. Supp. 764, 768 (E.D. Pa. 1974).

Congress did recognize, however, that Asian Pacific Americans suffered from the same "educational disadvantage[s]; racial disparities in proportions registered to vote; barriers obstructing equal opportunity for political participation ... ; [and] past discrimination" that other racial and language minorities suffered to justify their inclusion for protection as language minorities. See Loo, supra note 137, at 496 (footnotes omitted).

145 Asian languages are not of the Indo-European family and do not have Roman writing systems. See Loo, supra note 137 , at 512.

${ }^{146}$ See id. at 511 . 
covered jurisdictions are excluded from the political process because of illiteracy, not simply a lack of English skills. ${ }^{147}$

In addition to the difficulties previously mentioned, the inability to acquire English language skills stems from the stress of immigration, psychological and emotional conflicts, and the resultant identity change with a loss in self-esteem. Difficulty in learning to read and write English is thus not an indication of Asian Pacific Americans' unwillingness to learn the language. ${ }^{148}$ The dangers of a lack of bilingual assistance for such a significant activity as voting include exclusion and isolation from the surrounding society.

\section{Suggested Modifications OF PRINCIPLES/POLICY AND ALTERNATIVE REMEDIES}

Dismantling the subtle and effective discriminatory barriers against Asian Pacific Americans' voting rights demands an affirmative commitment to the political equality of Asian Pacific Americans. Without such a commitment, "true equality [for Asian Pacific Americans] ... remains elusive so long as the law is merely passive in conferring equality. Discrimination will persist in a system that is indifferent to the social realities confronting Asian immigrants." 149 The federal government and the judiciary must utilize the Voting Rights Act to pursue its intended goals affirmatively. ${ }^{150}$

\section{A. Affirmative Judicial Intervention and Fashioning of Innovative Remedies}

When faced with vote dilution cases, courts should not hesitate to intervene to invalidate the electoral structure being challenged and to fashion innovative remedies. Political equality for Asian Pacific Americans consists of equality in opportunity to participate,

147 Din argues that the Asian Pacific American voter registration rate should be "examined in light of its high median age and large percentage of persons who speak English not well or not at all." $\mathrm{He}$ cautions that the low voter registration figure is not likely to change especially with the defeat of bilingual ballot measures. See G. Din supra note 18, at 82 .

${ }^{148}$ See Loo, supra note 137, at 498-500.

$149 \mathrm{Kim} \&$ Kim, supra note 87 , at 406 .

150 See Guinier, supra note 32, at 395 (arguing that the Bush administration should reclaim the Voting Rights Act for those groups that it was to benefit and that this reclamation should include promoting the political futures of minorities through actual, not artificial, representation). 
to have an effective voice, and to have an Asian Pacific American presence in the voting booth and in public offices. ${ }^{151} \mathrm{~A}$ determination of political cohesion of Asian Pacific Americans should not depend exclusively on geographic insularity and polarized voting, but should also consider their distinctive interests and demonstrated collective action. Thus where the electoral system being challenged is not an at-large system, or the minority group is not geographically compact, alternative theories of inclusion and alternative remedies to single member districts must be utilized.

Alternative remedies that "lower the threshold of exclusion" and promote "greater diversity on governing bodies by increasing the number of groups large enough to elect the representatives of their choice 152 have already been tested. For instance, limited voting and cumulative voting are credited with lowering the threshold of exclusion, and with allowing the election of greater numbers of minority candidates. ${ }^{153}$

Furthermore, the Gingles' interpretation of section 2 (or at least the lower courts' construction of the Gingles' interpretation) is not necessarily the only approach to section 2 cases. As Judge Myron Thompson proposed in Dillard $v$. Crenshaw County, ${ }^{154}$ and as Karlan encourages, courts should "take Gingles at its word: dilution occurs when 'minority voters [would] possess the potential to elect representatives in the absence of the challenged structure or of practice...."155

151 The Voting Rights Act Amendment of 1982, Gingles, and scholars such as Karlan, Abrams, and Guinier all advocate a functional approach to address the problem of vote dilution.

152 Karlan, supra note 32, at 223.

153 See id. at 248 (concluding that "it is time for federal courts to be equally creative in developing a theory of liability under Section 2 that recognizes that minority vote dilution is not always simply a product of atlarge as opposed to district-based elections and to develop remedies of equal ingenuity finally to fulfill the promise of civic inclusion."); Still, Alternatives to Single Member Districts, in MINORTY VOTE DILUTION, supra note 112, at 249, 264 (criticizing the "winner take all" method of American politics): Karlan and Still also discuss fully the alternatives of limited voting and cumulative voting. See Karlan, supra note 32, at 221-36; Still, supra, at 253-58.

${ }^{154} 649$ F. Supp. 289, 294 (M.D. Ala. 1986). Judge Thompson cites the Senate Report and Gingles, and states that "the plaintiffs must show that, under the totality of circumstances, the challenged electoral scheme results in an unequal access to the electoral process." He further states that "the question whether the political processes are 'equally open' depends upon a searching evaluation of the 'past and present reality' and 'on a functional' view of the political process." Id. (citations omitted).

155 Karlan, supra note 32, at: 212 (quoting Gingles, 478 U.S. at 50 n.17). She 
In sum, the courts should take a "functional view"-that of a very local appraisal in light of present realities-to define the Gingles' prongs. A local appraisal of Asian Pacific American vote dilution, then, would consider the present "realities" through the prism of the Senate Report factors. Factors relevant to the situation of Asian Pacific Americans (and which can be established by anecdotal testimonies of qualified lay witnesses and community activists as well as by statistical data) are

any history of official discrimination in the state or political subdivision that touched the right of the members of the minority group to register, to vote, or otherwise to participate in the democratic process; ... the extent to which the state or political subdivision has used unusually large election districts, majority vote requirements, anti-single shot provisions, or other voting practices or procedures that may enhance the opportunity for discrimination against the minority group; . . . the extent to which members of the minority group ... bear the effects of discrimination in such areas as education, employment and health, which hinder their ability to participate effectively in the political process; ... the extent to which members of the minority group have been elected to public office in the jurisdiction; ... [and] whether there is a significant lack of responsiveness on the part of elected officials to the particularized needs of the members of the minority group. ${ }^{156}$

When applying these factors, courts must bear in mind the Senate's admonition that "the Committee intends that there is no requirement that any particular number of factors be proved, or that a majority of them point one way or the other. ${ }^{n 157}$ Thus the Senate Report factors should serve as flexible guidelines for the courts rather than as liability thresholds.

\section{B. Legislative Changes}

To protect Asian Pacific Americans' voting rights, modifications to the multilingual provisions of the Voting Rights Act also need to be made when the Act is considered for renewal in $1992 .{ }^{158}$ The

further argues that "[g]eographic compactness has been transformed from a shorthand expression for broadly inclusionary values into a way of short circuiting claims of racial vote dilution." Id. at 210 .

${ }^{156}$ S. REP. No. 598, 97th Cong., 2d Sess. 28-29 (1982) (footnotes omitted).

157 Id. at 29.

158 See id. at 8-9 (describing past modifications to the Voting Rights Act in order to safeguard the rights of non-English speaking citizens); $i d$. at 10 
most significant modification is altering the trigger factor for determining coverage under the Voting Rights Act. The five percent trigger for coverage should be replaced with a fixed number of language minority voters. ${ }^{159}$ A lower trigger figure for bilingual assistance will help to ensure that non-English speaking Asian Pacific Americans who comprise less than five percent of the voting age population are protected. ${ }^{160}$ In turn, when greater numbers of Asian Pacific Americans are provided with bilingual voting assistance, greater numbers will register to vote, and the Asian Pacific American electorate will grow in strength. ${ }^{161}$

\section{CONCLUSION}

Currently, Asian Pacific Americans' impact on electoral politics is significant in terms of its potential rather than present impact. ${ }^{162}$ In order to realize that potential, any situation in which it is shown that Asian Pacific Americans "have less opportunity than other members of the electorate to participate in the political process and to elect representatives of their choice"163 must be effectively remedied. To include Asian Pacific Americans in the electoral process, "specific local communities and ethnic groups which deserve greater attention" 164 must be pinpointed and

(finding that language discrimination has persisted and must be corrected).

159 See supra notes $124-26$ and accompanying text (discussing the diffusion of Asian Pacific American voters).

${ }^{160}$ Both Loo and the Yale Law Joumal Note advocate an elimination of the 5\% trigger. See Loo, supra note 137, at 513 (advocating "changing the criteria for language assistance in the electoral process from a percent of a jurisdiction's voting-age citizens to an absolute number of the voting-age citizens of a single language minority in a particular political subdivision so that those language minorities that primarily reside in large urban areas will not be at a disadvantage"); Note, supra note 142, at 1436 (presenting policy suggestions including replacing the $5 \%$ trigger with a fixed numerical trigger such as 1000 non-English speaking citizens).

Loo and the Note also address and rebut common arguments against a more inclusive trigger percentage or number such as that the costs of including more individuals for language minority provisions' protection and services provided will be prohibitive, that a use of any trigger figure will still continue to exclude some, and that such bilingual services will decrease non-English speakers' incentive to learn English. See Loo, supra note 137, at 495, 506; Note, supra note 142, at 1433-36.

161 See H.R. REP. No. 97-227, 97th Cong., 1st Sess. 27 (1981).

162 See UCLA Study, supra note 18, at 16.

16342 U.S.C. $\$ 1973$ (b) (1982).

164 UCLA Study, supra note 18 , at 16 . The study further notes: 
served. The final goal of political equality for Asian Pacific Americans, then, is a guarantee of an equal opportunity for Asian Pacific Americans to participate in politics and to have an effective voice which will encourage greater and more active participation.

[L]ike many citizens, Asian Pacific Americans will be influenced by the issues, events, and political climates of their local communities. For example, the extent to which local political leaders come to grips with and meaningfully resolve controversial and highly emotional issues such as the campaigns to declare English as the official language in cities such as Monterey Park and Alhambra may either lead to political alienation, or have the opposite effect of compelling Asian Pacific Americans to have a greater stake in local affairs.

Id. at 8. 


\section{.}

